\title{
Elise Lindberg
}

- en privatlærerinde »i nationalitetskampens

og den folkelige oplysnings tjeneste"

\section{af Birgit Kaiser}

Forud for Genforeningen i 1920 gik fem årtiers bestræbelser for at bevare og støtte danskheden i Nordslesvig. Privatlærere og vandrelærere søgte at modarbejde påvirkningen for den gradvist fortyskede folkeskole. Den første i rækken af danske privatlærerinder var Elise Lindberg. Hun virkede som privatlærerinde fra $1872 \mathrm{og}$ drev et hjem for unge piger i Visby, indtil hun blev udvist i 1884. Mag. art. Birgit Kaiser, Birkerød, fortæller her om denne pioner $i$ en overgangstid.

"... Lise er nu Husets Dame, hun spiller nogenlunde Fortepiano, maler ret smukt Blomster efter Naturen, kommer i fine Selskaber og danse med Stiftamtmanden. Dette sidste maa nok være sket ved en Fejltagelse; thi det var den eneste Dans, han dansede, og han og jeg enes som Hund og Kat, saa det skulde være sært, han tog hende op. Ellers syer hun smukt, baade til sin Moder, sig selv og Anna, men læser dog helst, og da hun længe med Lethed har læst Tysk, saa studerer hun nu Fransk og langes efter at faa Niels igen, da han har lovet at lære hende Engelsk ... Du har her en Skildring af mit Husliv, som jeg véd vil fornøje dig. Kære Søster, min hjerteligste Tak for dit Brev og Hilsen til dig, til Niels og hans Kone og Børn fra mig og fra os alle. Gud glæde dig nu og altid. Din Broder Jac. Chr. Lindberg «. ${ }^{1}$

Brevet er skrevet i slutningen af 1840 'rne, og ingen er vel i tvivl om, hvilken fremtid den brevskrivende far tiltænkte datteren Elise Christiane, af familien kaldet Lise. Men hendes liv kom til at forme sig helt anderledes, end faderen havde tænkt sig. 1800-årenes Danmark var de store forandringers tid, og Elise Lindberg blev en af århundredets mange kvindelige pionerer. ${ }^{2}$

\section{Barndomshjemmet}

Elise Lindberg blev født den 15. september 1832 på Christianshavn og voksede op i et magister-, præste- og politikerhjem. Faderen, Jakob Christian Lindberg, var teolog og en stor begavelse, ${ }^{3}$ som blev kendt af en større offentlighed under Kirkekampen. Moderen, Anna Cathrine Elisabeth Hansen, kom fra det velstående københavnske borgerskab. ${ }^{4}$ Forældrene blev viet af Grundtvig i Vor Frelser kirke foråret 1826, netop som Kirkekampen var begyndt. ${ }^{5}$ 
Efteråret 1836 flyttede familien ud på Frederiksberg. Den omfattede foruden forældrene og fire børn også moderens voksne søskende Laura, Jørgen og Ludvig samt faderens søstersøn Carl Alberti. De tre unge mænd studerede og underviste børnene til gengæld for opholdet. På Alléenberg forøgedes familien med endnu to børn. ${ }^{6}$ I det gastfrie hjem kom vakte fra hele landet og familiens venner, blandt hvilke taltes P.C. og Søren Kierkegaard, Frederik og Martin Hammerich, Peter Rørdam, Theodor og Ferdinand Fenger, Emil Clausen, Ludvig og Valdemar Møller, Frits, Peter og Harald Bojsen, Frederik Barfod, »den gamle Præst« Jens Hornsyld, Grundtvig og hans datter Meta.

I 1842 flyttede familien igen, denne gang til Frontiers Gaard i Allégade, i baghuset. Økonomien havde været anstrengt siden 1830, da faderen måtte gå fra Metropolitanskolen. Han ernærede sig ved skribentvirksomhed og lidt undervisning. I flere år betalte en kreds af præster hans husleje, ligesom han modtog pengegaver fra flere venner. ${ }^{7}$ Foråret $1844 \mathrm{blev}$ han, formentlig hjulpet af dronning Caroline Amalie, udnævnt til sognepræst i Tingsted på Falster. ${ }^{8}$

På Falster blev Jørgen født, og faderen afsluttede den bibeloversættelse, som udkom 1837-53. Omgangskredsen blev udvidet og omfattede nu også bl.a. Monrad, der blev biskop over Lolland og Falster, da han trådte af som minister.

Sommeren 1854 tog familien på en rundrejse i Slesvig. Faderen, der i 1853 var blevet indvalgt i folketinget, var af tinget valgt ind i Helstatens tysk-danske forsamling Rigsrådet. De slesvigske forhold lå ham stærkt på sinde, og i præstegården diskuteredes de indviklede forhold dernede, især Moltkes sprogreskript, både med børnene og med familiens venner. ${ }^{9}$

I oktober 1854 rejste Elise med faderen til København, hvor han skulle passe sit arbejde på tinge, og det gentog sig året efter. Hun boede hos Albertis, og kort før hjemrejsen foreslog tanten hende at bede faderen om lov til at blive i København »og læse hos frøken Zahle, der nylig havde oprettet sin skole for unge piger, som ønskede at uddanne sig til lærinder «. ${ }^{10}$ Hun opnåede ikke hans samtykke; han "ville ikke have en Gouvernante til Datter«.

Foråret 1857 søgte faderen et større embede, Lille Lyngby nær Arresø, og fik det. Nogle måneder senere blev han angrebet af tyfus og døde den 10. december samme år.

Efter begravelsen lejede moderen en lejlighed på Frederiksberg. ${ }^{11}$ De havde ikke meget at rutte med. Arven efter faderen var indtægterne fra bibeloversæettelsen. Et stort møntværk, som han arbejdede på, var ikke færdigt, da han døde, men udkom posthumt, da professor Ludvig Vestergaard, den eneste der kunne fuldføre det, påtog sig opgaven. Dertil kom nådensåret og i 1857-58 et nyt oplag af bibelen. Familiens omgangskreds blev nu »Grundtvig og professor Stephens på Gl.Kongevej ... Kietzes, Albertis, Moltkes o.fl.«. De gjorde 
Elise Lindberg. Foto: Det kongelige Bibliotek.

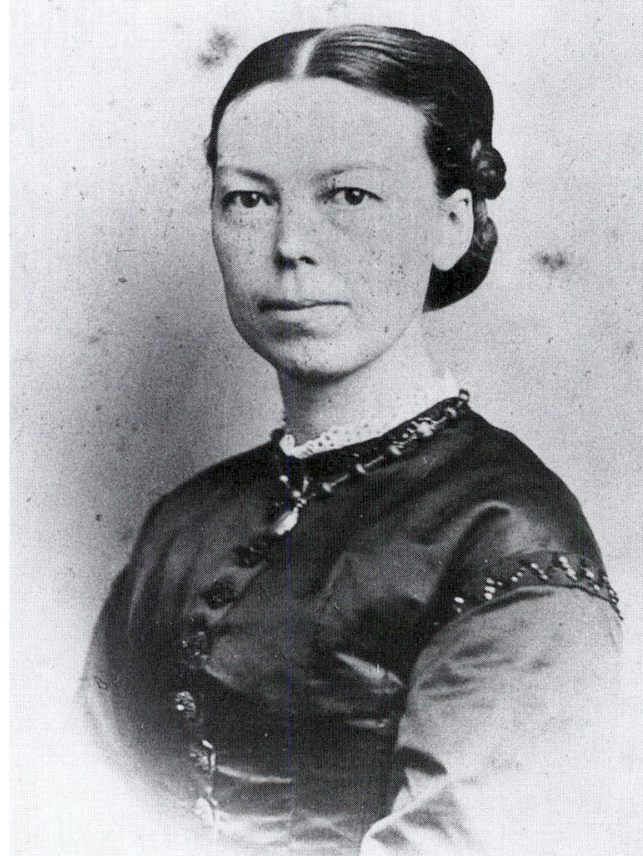


Men det forblev ved tanken dengang. Moderen kunne ikke forstå det og behøvede hende desuden derhjemme. Broderen Niels mente ikke, hun kunne klare alle de afsavn, som nødvendigvis måtte blive en følge, og rådede hende fra det. Heller ikke nu blev det til noget; hun følte sig ikke stærk nok. Grundet Niels's ægteskab ville hun imidlertid forlade hjemmet på Frederiksberg. Hun skrev til svigerinden Amalie, gift med broderen Jens, som havde købt en gård i Kastbjerg, og spurgte, om hun kunne bo dér mod at undervise familiens børn, og en aftale kom i stand.

I september 1871 flyttede hun så ind i de to værelser, hun som et led $\mathrm{i}$ aftalen havde bekostet bygget til broderens stuehus i Kastbjerg. Her begyndte hun straks at undervise den 6-årige Anna, og kort tid efter også et par voksne unge piger hver lørdag eftermiddag. ${ }^{14}$ På den måde gik godt og vel tre år.

Den 13. december 1871 skrev Elise Lindberg til højskoleforstander Ludvig Schrøder i Askov. I brevet takker hun for de dage, hun har tilbragt dér om sommeren og skriver om lidt almindeligheder, for så endelig at komme til sagen: »det er nu, at min broder her i Kastberg, som i flere år har havt det trangt, da høsten har været så uheldig, nu har han besluttet at sælge gården, så snart lejlighed gives og følgelig må vi vel så hver drage sine veje ... Nu har jeg tænkt om ikke De, der kender så mange egne her i landet, og så mange mennesker, kunne tænke Dem et sted hvor jeg kunne drage hen og undervise børn, ti de voksne er det vel ikke verd at tænke på. Jeg kan fortælle bibelhistorie og historie og jordbeskrivelse, og det er mig selv en fornøjelse, jeg kan virkelig gøre det med glæde«. Hun nævner den gamle drøm om at undervise i Sønderjylland og fortsætter: »Jeg tænkte ofte på det i sommer da jeg var dernede, men da jeg jo var her, og dengang ikke vidste at min broder tænkte for alvor på at flytte, syntes jeg heller ingen grund der var til at tale om slige ting ... Nu i dette efterår, da jeg jo ser at Tysk er indført i skolerne, nu kom jeg atter til at tænke over den sag, og har mange gange ønsket at jeg vidste om der kunne holdes skole for Danske børn på landet dernede. Undertiden har jeg tænkt at en kvinde måske kunne udrette lidt dér, netop fordi hun behøver en mindre kreds at bevæge sig i end manden, og derfor måske ville kunne arbejde mere ubemærket. - Jeg ved med mig selv, at jeg nu ville være langt bedre skikket til det end den gang jeg først tænkte derpå. Jeg har selv gået fuldt så meget i skole, som mine elever, i de tre år jeg har været her, og jeg har nu lært at undvære meget, både åndelig og materielt velvære, som jeg dengang havde fuldt op af ... Engang når De kan få tid og lyst, så sig mig Deres mening om denne sag, og tænk ellers på, om jeg ikke skulle kunne bringes til at tage om end nok så lille en del i den folkelige oplysnings sag, som jeg er hjertelig hengiven . $^{15}$

Schrøders svar lod vente på sig. Først den 29. februar 1872 sendte han hende et brev, som han samme dag havde modtaget fra en sønderjysk lærer M. Rosendal, en edsnægter i Råhede i Hviding sogn, der spurgte, om Schrøder kunne 
anvise en lærerinde til den stedlige møller Niels Brodersen. Schrøder skrev bl.a.: "Når De nu vil læese det og overveje det, så vil jeg derhos bede Dem betænke, at jeg næppe før næste 29. febr. får et lignende, så at De vist må prøve på at få noget ud af denne sag, dersom De overhovedet har mod på at prøve den ramme virkelighed, der svarer til deres phantasislotte«. Han gjorde opmærksom på, at hun ved at tage til Råhede kom ind $\mathrm{i}$ hans kreds, bl.a. fordi Råhedes mest indflydelsesrige mand Peder Moltesen på anden vinter havde en søn på Askov. Endvidere at Råhede kun lå " 5 fjerdingvej syd for Ribe, så at De ved at komme dér kommer i nærheden af deres gamle faster, af den lille pastor Bertelsen på Manø og af adskillige andre mennesker, De kan have glæde af ...«. Hvad møllerfamilien angik, var konen værtshusholderdatter fra Ribe, hvilket Schrøder mente ville gøre det lettere at finde sig tilrette i huset.

I en efterskrift tilføjede han: "Dersom det generer Dem at forlange en løn, kan De skrive til mig, hvormeget jeg skal foreslå de folk at give Dem. Forresten er det jo vejen til at kunne trænge længere frem i Sønderjylland, om det lykkes her, så det bør ikke komme an på lønnen «. ${ }^{16}$

Ugifte kvinder af stand, men uden midler eller uddannelse, og den kategori hørte Elise Lindberg til, havde ikke mange fremtider at vælge imellem dengang, når barndomshjemmet blev endeligt opløst. Da Elise Lindberg stod og skulle vælge, var der dog andet at vælge end skyggetantetilværelsen hos slægtninge eller en gouvernantestilling, når man som hun ville undervise.

Mulighederne lå indenfor det offentlige skolevæsen, hvor man kunne blive håndgerningslærerinde. Så sent som i 1894, 35 år efter at kvinder fik adgang til at aflægge lærerindeeksamen, var disciplinen stadig kun skemaført i 466 af landets 3113 landsbyskoler; uddannede lærerinder var en mangelvare. Endvidere var der pogeskolen, både kommunal og privat, som blev genopfundet i 1856 for at afhjælpe overfyldning af skoleklasserne, og også her kunne kvinder få ansættelse uden lærerindeeksamen. Set fra en lønmæssig synsvinkel var disse embeder formentlig ikke særlig eftertragtelsesværdige. Lønnen for en lærerinde i pogeskolen var indtil $200 \mathrm{kr}$. om året plus bolig, brændsel og eventuel betaling for håndarbejdsundervisning. ${ }^{17}$ Men de betød, at man havde eget tag over hovedet.

Reelt set var der tale om et valg mellem flere onder, da Elise Lindberg forlod barndomshjemmet i 1868. Men det var der næppe i 1872; da havde hun ikke noget valg bortset fra valget mellem Kongeriget og Slesvig.

\section{Privatlærerinde i Råhede}

Den 1. maj 1872 tiltrådte Elise Lindberg stillingen som lærerinde for møller Niels Brodersens børn. Hun stod nu, 30 år gammel, for første gang på egne 
ben. Hun kendte møllerens forventninger gennem brevet fra lærer Rosendal, hvis plads hun overtog. Møllerens ønskede en lærerinde, som foruden de almindelige skolefag også kunne undervise i håndarbejde. ${ }^{18}$ Af betænkeligheder havde hun blot én: hun regnede kun mådeligt og kun med små børn. "Men«, skrev hun til Schrøder, »da jeg igrunden selv synes, at regning ikke er nogen hovedsag, navnlig for små piger ... så [har] den sag hidindtil ikke hvilet tungt på mig«. Lønnen, som mølleren fastsatte, var kost og logi, men ikke vask, samt 50 rd. årligt. ${ }^{19}$

Mødet med møllerens blev et chok. Den stue, Elise Lindberg skulle have, var lille, soveværelset ligeså, og endnu ikke sat i stand. Væggene var af rå kalk, og der var hverken gardiner eller rullegardiner for vinduerne. Gulvene var snavsede, møblementet sparsomt og værkbrudent. Servicet var skåret, og i sengen lå gammel halm. Møllerkonen »skvaldrede op«, og børnene lignede »københavnsk gadeungdom".

Udfra en nøgtern betragtning var der tale om et kultursammenstød; der er større afstand mellem et præstehjem og en møllerstue, end man tror. Rosendal havde gjort opmærksom på, at møllerens ønskede en, der ville finde sig til rette $\mathrm{i}$ et bondehus og ikke en fin dame, hvilket Elise Lindberg måtte have overset. Hun indså straks, at dér kunne hun ikke blive, men ville dog se tiden an.

Før sommerferien fik Elise Lindberg besked om at give møde med børnene til provstevisitats. Hun gruede, da børnene jo ikke lærte tysk, men de svarede tilfredsstillende på alle spørgsmål. Skriftprøven forløb også godt, bortset fra, at provsten var utilfreds med deres stavemåde, som var efter Lyngbys system. Oplæsningen på tysk kunne de imidlertid ikke klare, hvilket gav anledning til det første sammenstød med de tyske myndigheder. Da provsten anmodede hende om at lære dem lidt tysk, svarede hun, at det kunne hun ikke, det var imod forældrenes ønske. Samtalen udviklede sig, og det endte med, at hun til provstens store forundring sagde, at hun ikke beherskede sproget.

Bagefter fortrød hun dog sin fremgangsmåde, "... det blev mig aldeles indlysende, at vi under de nærværende forhold ikke kunne vedblive at nægte at lære børnene tysk, og jeg angrede at jeg selv i en god hensigt havde kunnet få mig til at sige, at jeg ikke kunne tysk «. Ved lærermødet på Askov lånte hun et par tyske bøger af Nutzhorn og begyndte efter ferien at læse lidt tysk med børnene. ${ }^{20 a}$ Fra det tidspunkt indrettede hun sig altid således, at præsten kunne være tilfreds med hende i det spørgsmål. Hun stod endda, som hun selv udtrykker det, "med palmerne i hænderne blandt egnens degne, netop i tysk!«.

I begyndelsen af september meddelte Elise Lindberg mølleren, at hun ønskede at rejse. Hun havde ikke fundet et nyt hjem og ville derfor rejse til Kastberg og se tiden an. Da hun besøgte Peder Moltesen for at tage afsked, fortalte han 
imidlertid, at de dansksindede ønskede, hun blev i landsdelen, og at Martha og Jens Brodersen i Hviding gerne ville have hende som lærerinde for deres tre piger.

\section{Hos Brodersens i Hviding}

Den 1.oktober 1872 flyttede Elise Lindberg ind hos Brodersens. Hun havde bundet sig for et år til en løn på 100 rd., kost og logi. Desuden havde hun betinget sig ny halm i sengen, et varmt værelse om vinteren, en venlig omgang og at de ville vaske hendes tøj.

Familien Brodersen faldt mere i Elise Lindbergs smag, fremgår det af et brev til Schrøder. Manden havde fået sin opdragelse i brødremenighedens kostskole i Christiansfeld, men gik helt ind for det danske. Det ældste barn, en søn, var blevet taget ud af skolen, da der skulle undervises på tysk, og sendt til Fyn. Ingen af pigerne havde gået i skole undtagen den ældste, som i en periode gik i skole i Øster Vedsted, hvor hun opholdt sig hos Brodersens søster, indtil hun skulle ud at tjene sommeren $1872 .{ }^{20}$ Martha syntes Elise Lindberg også om; hun var grundtvigianer, uden Brodersens vidende, og havde en broder, som var lærer på Ryslinge Højskole. ${ }^{21}$

Seks timer hver dag holdt Elise Lindberg skole. Der var fem elever, da to piger fra andre familier også meldte sig. Hver dag fik børnene undervisning i læsning, skønskrivning, danmarkshistorie og bibelhistorie. De begyndte dagen med Fader Vor og Morgenstund har Guld i Mund og sluttede den med Sov sødelig, sov blødelig, luk dine Øjne.

Men hun ville gerne gøre noget mere for danskheden. Da børnene i Nordslesvig havde fri fra skole hver onsdag og lørdag eftermiddag, ville hun forsøge at samle nogle af dem, fortælle danmarkshistorie og bibelhistorie og synge med dem. Martha og Jens Brodersen var med på ideen, men ingen børn meldte sig. I stedet holdt hun så, ligesom i almueskolen, syskole for de fem elever, hun havde, og de eftermiddage mødte yderligere tre elever op, to fra Råhede og én fra Høgsbro.

\section{Aftenskole og husflidsforening}

Efter nytår 1873 begyndte hun at holde en slags aftenskole for børnene i 1213 års alderen. Piger og drenge, både husmandsbørn og gårdmandsbørn, kom to aftener om ugen for at høre danmarkshistorie og synge fædrelandssange. Hun tog ingen betaling. Jens Brodersen var lydhør overfor initiativet og selv 
tilhører. Om foråret fortsatte skolen efter børnenes eget ønske, men begyndte en time senere, så at de, der var ude i sommertjeneste, kunne nå at flytte kreaturer, før skolen begyndte kl. 7 .

Efter ferien måtte aftenskolen udvides. Børnene ville også gerne høre bibelhistorie, og så mødte de op tre aftener om ugen. Og da de sad og lavede småarbejder, fik hun den tanke, at der burde oprettes en husflidsforening i Hviding, »hvorved Flere kunde samles og faa Lyst til forskellige Hjemmearbejder, ti i den Retning stod hele denne Egn langt tilbage; Mændene og de unge Karle drev hele Aftenen, naar de ikke spillede Kort «. Det ærgrede hende også, at kvinderne ikke selv forarbejdede egnens fine uld fra grunden, og at døtrene kun hæklede.

Planen vandt ikke tilslutning i første omgang, men senere, vistnok i februar 1874, oprettedes en husflidsforening i Hviding.

Kristi Himmelfartsdag 1874 skrev Elise Lindberg til Ludvig Schrøder. Hun havde set en opfordring til at virke for den danske sag i Sønderjylland, underskrevet af bl.a. Schrøder, og spurgte, om han kendte nogen, der virkede for søndagsskoler. Det må have være en føler, for ved samme lejlighed fortalte hun, at aftalen med Brodersen ikke blev fornyet. Der var ingen uoverensstemmelser, men han havde ikke råd til at lønne hende, og ingen andre familier ville være med til at betale. "Det er nu ogsaa en kendsgerning«, fortsatte hun, wat befolkningen, på nogle ganske få undtagelser nær, virkelig slet ikke er misfornøjet med det tyske skolevæsen, og fremfor alt, ikke vil betale en skilling for at få børnene undervist udenfor skolen «. ${ }^{22}$

Den 27.juli skrev hun til Schrøder igen. Brodersen havde tilbudt at hun kunne blive, hvis hun havde lyst, men uden løn! Hun fandt forslaget underligt, men da hun havde mere lyst til at blive end til at rejse, ville hun den følgende dag komme til Askov for at drøfte sagen med ham. - Schrøder rådede hende til at blive hos Brodersens, nu da "sagen er kommen i saa god en Gang«. Han ville så forsøge at skaffe hende økonomisk støtte fra Foreningen »Dannebrog«.

Efter at have deltaget i det årlige lærermøde på Askov, hvor hun gjorde bekendtskab med bl.a. skolebestyrer C. F. Monrad fra Flensborg og rektor Lefolii, rejste hun tilbage til Hviding. Dog først efter at have aflagt besøg hos Thyssens og Niels Andersen i Randerup, Becks i Visby og pastor Gottlieb i Skast, alle hørende til kredsen. I Hviding kom hun straks overens med Brodersen om det, Schrøder havde rådet hende til.

Det var åbenbart ingen dårlig idé at blive hos Brodersens. Elise Lindberg er tilfreds. Hun sporer fremgang, og for hende selv falder alt også lettere end i den første tid - »denne sag har fremtiden for sig«. Hun underviser Brodersens børn seks timer om dagen. Mandag, onsdag og lørdag aften holder hun tillige aftenskole for omkring tyve større piger og drenge i konfirmationsalderen. Om 
mandagen fortæller hun bibelhistorie, bruger Bojsens bibelske sange, og de to andre aftener sagaer og danmarkshistorie. „Vi bruger da Deres visebog, « skrev hun til Schrøder, »men i lidt forbedret udgave, idet jeg nemlig bag i bogen har skrevet faders sang, som jeg savnede i selve bogen . $^{23}$

\section{Omgangslærerinde i Randerup og Lunde}

I februar 1874 bad hun på husflidsforeningens vegne den kendte husflidsmand, lærer N.C.Rom om at komme og fortælle om husflidens betydning, og ved den lejlighed forærede han hende en krans af 90 små udskårne pinde, som drengene skulle gøre efter »som opøvelse i at bruge kniven«.

Dagen efter Roms besøg blev Brodersens datter Ane syg og døde få dage derefter. Dødsfaldet gjorde så stort indtryk på Brodersen, at han tre uger senere solgte gården til afståelse 1. maj 1874. „Denne Efterretning kom mig hel uventet«, skriver Elise Lindberg, »og nu saa det ud som om jeg selv kunde blive uden Plads. Jeg skrev til fru Nielsen i Kassø, til Margrethe Thyssen i Randerup og Georgia la Cour paa Rødding Høiskole, at om de vidste nogen Plads der kunde tiltrædes 1 . April, maatte de endelig lade mig det vide, ti til den Tid flytter jeg fra Hvidding «. - Dagen efter stod Thyssen fra Randerup hos Brodersens og spurgte, om hun ville komme og undervise tre familiers børn. Der var tale om tolv børn, fra 12 år og derunder, lønnen var $100 \mathrm{dl}$. om året.

Skolestuen i Randerup, der også skulle fungere som Elise Lindbergs private stue, var et lyst og rummeligt loftskammer med sydvendte vinduer. Før hun begynder skolen, aflægger hun besøg hos sognepræsten, pastor Thiessen, fortæller ham, at hun skal undervise Thyssens børn, og at Hans Andersen fra Forballum, Thyssens broder, og Hans Moltesen fra Lunde ønsker, at deres børn deltager. Tror han, det kan gå an? Hun beder endvidere om råd med hensyn til, hvordan hun helst skal indrette sig med skolen; hun er fremmed på egnen og vil ikke støde mod love eller forordninger, sådan som det skete, da hun første gang kom til landsdelen.

Resultatet blev, at skolen kunne begynde, uden at hun først skulle eksamineres af provsten i Møgeltønder. Thiessen ville snarest overvære undervisningen og derefter tage stilling til eventuelle forandringer i undervisningsplanen. Nogle dage senere aflagde pastoren besøg og erklærede sig tilfreds med, hvad han hørte og så. ${ }^{24}$

Forholdene i Randerup var meget anderledes end i Hviding. Elise Lindberg nævner i erindringerne, at beboerne i Randerup var gammel-pietistiske, at der var en del fattigfolk $i$ byen, og at skellet mellem gårdmænd og husmænd var 
meget fremtrædende. Hidtil havde hun rejst omkring for at dyrke sin kreds, når hun havde lyst, men det var slut nu. Hos Thyssen var der tale om en stilling, som skulle tages alvorligt. Da hun f.eks. en dag bad ham køre sig til Brede eller Skærbæk, så at hun kunne tage diligencen til Ribe for at være sammen med broderen Jørgen et par dage, svarede han, at det kunne der ikke være tale om »på denne tid«, hun måtte passe skolen.

Om Thyssen blev årsag til, at undervisningen nu synes at have fået en fastere form, eller at hun var blevet dygtigere, vides ikke. Men i hvert fald lagde hun nu et skema, som blev fulgt de kommende godt og vel fire år, og hun besluttede, hvilke bøger der skulle anvendes: »Mandag formiddag: Skønskrivning, regning, fortælling af Danmarks historie. Eftermiddag: Naturhistorie, dansk stil, tegning, indenads læsning. Tirsdag formiddag: Bibelhistorie, skønskrivning, regning, indenads læsning. Eftermiddag: Tysk, geografi, tegning. Onsdag formiddag: fortælling af verdens historie, skønskrivning, indenads læsning. Om eftermiddagen: syskole. De tre følgende dage ligesom disse, men lørdag eftermiddag fri ... Nu kommer vi til læsebøgerne. Til mindste klasse havde jeg fru Hejns, til anden Andersens æeventyr, til tredje Sakse og faders bibel. Jeg havde 3 eksemplarer af hver. I tysk havde børnene hidindtil kun læst i fibelen, men den kunne de intet lære af, og jeg bad præsten anbefale mig en tysk læsebog, som var lidt morsom. Det gik han straks ind på, og foreslog Grimms æventyr, som jeg også var tilfreds med ... Vi brugte Grünfeldts Regnebog, der er meget sværere end Hansens Danske Regnebøger, men de sønderjyske børn er fødte regnemestre, og utrolig dygtige i dette fag «. Hun forlangte endvidere, at børnene skulle kunne »Fengers Bibelhistorie, Kofoeds lille Verdenshistorie, Lytkens lille Naturhistorie og Grøndals lille Geografi«.25

Før sommerferien arrangerede hun en tur til Hviding for at se husflidsforeningens første udstilling. Alle børnene var med. Thyssen, Hans Moltesen og Hans Andersen stod for kørslen. Det vakte så stor interesse for husfliden hos både børn og voksne, at Thyssen bad hende om at få lavet et skejern hos smeden i Kastbjerg, mens hun opholdt sig hos familien dér.

I november begyndte hun at holde aftenskole med de større børn i sognet en gang om ugen. Atten børn mødte op. Det var flere end skolestuen kunne rumme, så Thyssens dagligstue blev inddraget. ${ }^{26}$ Drengene skar efter Roms anvisning, og da flere af de voksne fik lyst til at prove det samme, sendte Thyssen bud efter en mand fra Visby, som skulle lære dem kunsten. Omkring årsskiftet $1874-75$ oprettedes en husflidsforening, først i Mjolden og derefter i Randerup.

Den 1. september 1876 flyttede Elise Lindberg til Lunde. Det var skik, at en lærerinde, der underviste flere familiers børn, boede hos de forskellige familier på skift, så at udgifterne kunne blive ligeligt fordelt. Det fremgår dog af erin- 
dringerne, at hun også var lidt træt af at være hos Thyssens. Hos Hans Moltesens i Lunde var betingelserne som i Thyssens hus, dog med en lille, men betydningsfuld tilføjelse - hun vil kaldes Frøken Lindberg. Det havde altid været hende ubehageligt at være dus med Thyssens kone Margrethe, men et krav fra Thyssen. - Hos Moltesens fik hun mere plads og kunne derfor modtage flere elever både i dag- og aftenskolen.

\section{"Sagen« fik det vanskeligere}

Ved instruks af 9. marts 1878 angående tyskundervisningen blev undervisning i tysk obligatorisk for samtlige elever i de nordslesvigske skoler, seks halve timer om ugen på yngste hold, tolv timer om ugen på ældste og ti på mellemste. Til den forste læseundervisning skulle hvert barn være i besiddelse af den tyske fibel, abc, og Den første Læsebog af K.F.Th.Schneider. På ældste hold af Kinderfreund af Schneider eller af Keck \& Johannsens Læsebog (i en udgave efter 1871) samt Gesangbuch für die evangelischen Schulen Schleswig-Holsteins. Instruksen indeholdt desuden en løfteparagraf, der gav beføjelser til frivilligt at gå videre, idet der stod: "At indføre tysk som undervisningssprog for samtlige fag, eventuelt med undtagelse af religion, kan for enkelte skoler af regeringen blive tilladt efter andragende af et flertal af skoleinteressenter og efter andragende af regeringen blive påbudt af overpræsidenten«.

Det var en stor mundfuld for de dansksindede lærere i Nordslesvig. Siden 1864 var kravene strammet flere gange. Den 22. januar 1867 udkom forordningen om edsaflæggelse. I august 1871 strammedes kravene igen. Der udsendtes en skoleinstruks, efter hvilken tysk blev obligatorisk undervisningsfag i alle nordslesvigske skoler. Dog ikke i de to første skoleår, men fra det tredje skulle også børn i landsbyskolerne have seks timers tyskundervisning om ugen. Kravet kunne imidlertid ikke gennemføres af den enkle årsag, at en stor del af lærerne ikke var i stand til at undervise i faget. ${ }^{27}$ Det blev derfor hverken særlig mærkbart eller synligt.

$\mathrm{Nu}$ i 1878 var den to-sprogede skole imidlertid skabt, og den gav de tyske myndigheder mulighed for at favorisere det tyske prog, hvilket dog ikke, som Elise Lindberg bl.a. nævner, stødte på modstand hos alle i befolkningen.

Skolebestyrer Monrad i Flensborg havde længe forudset, at hans skole kunne blive lukket. Den 3. februar 1878, altså før den nye lov blev publiceret, skrev han: »Det vil vist overraske Dem, kære Frøken Lindberg, når jeg fortæller Dem, at jeg til 1ste April afslutter min Virksomhed som Skolestyrer i Flensborg og overdrager min Skole til en af mine tidligere Lærerinder, der selv er dansksindet og kun har dansksindede Lærerinder ... Om Grunden til et så 
afgørende Skridt fra min Side, vil jeg her kun sige Dem såmeget, at det $\mathrm{i}$ Løbet af de sidste 2-3 År altid stærkere har påtrængt sig mig som en indre Nødvendighed endelig engang at komme til at stå som en fri Mand i Kampen, fordi jeg tror $\mathrm{i}$ en sådan friere Stilling at ville kunne udrette mere end i min nuværende, der er særdeles bunden navnlig ved de mange Hensyn, Skolen nøder mig til at tage .... ${ }^{28}$

Situationen tilspidsedes i Slesvig. Elise Lindberg havde god kontakt med mange privatlærerinder dernede. For at de kunne undgå at irritere myndighederne, holdt hun dem ajour med nye bestemmelser vedrørende skolevæsenet, som hun fik fra Monrad, og allerede nogle uger efter Monrads brev erfarede hun, at flere skoleråder krævede, at private skoler med danske lærerinder skulle lukkes, medmindre undervisningen foregik på tysk.

Den 3.juni 1878 kom præsten, som sædvanligt uanmeldt, til Moltesens for at holde eksamen. Han næunte ikke den nye lov med et ord, men derimod at han havde hørt, at skoleråden snart ville komme på besøg. Men da havde Elise Lindberg allerede lagt en ny plan.

\section{Hjælp fra kvindekreds i København}

I påsken 1878, da hun tilbragte et par dage hos grevinde Moltke i København, drøftedes den gamle idé om et hjem for unge piger. Skolebestyrer Susette Mariboe hørte om den og fandt den så udmærket, at hun inviterede Elise Lindberg til at forelægge den for en større kreds. Her udviklede Elisé Lindberg sine planer for den fremtidige undervisning. Hun ville nu ikke længere være afhængig af bønderne og kunne ikke forpligte sig til at holde skole, da de nye forhold gjorde det umuligt at avertere, men ville blive boende i Sønderjylland og skaffe elever via mund til mund metoden. De unge piger skulle betale 30 kr. om måneden ligesom på højskolerne, blive et år »og saa lære Historie, Geograf, Naturhistorie, Dansk, Tysk, Skrivning, Tegning, Haandarbejde« samt lidt huslighed. Når året var omme, ville hun skaffe dem plads som privatlærerinder, så at de kunne virke for danskheden. Økonomien ville kunne hænge sammen, hvis der blev skaffet $1200 \mathrm{kr}$. årligt fra legater og et lignende beløb fra foreningen $»$ Dannebrog $«$.

Ideen faldt $\mathrm{i}$ god jord. Kredsen ville støtte hende waf al Magt, det var ikke alene den Danske Sag, det var en Kvindesag«, skriver Elise Lindberg begejstret. Hvis hun ikke opnåede legater, ville damerne fremskaffe beløbet.

Den 4. juni skrev Monrad og inviterede Elise Lindberg et par dage i pinsen; han ville drøfte forskelligt med hende, mundtligt. ${ }^{29} \mathrm{Hvad}$ de drøftede, forblev imellem dem, men der er ikke tvivl om, at han støttede hende. De arbejdede 
for den samme sag, og han hørte tillige til Susette Mariboes vennekreds. I juli sendte Elise Lindberg så en anmodning om økonomisk støtte til Den RabenLevetzau'ske Fond, formentlig skrevet af Monrad, men fik afslag. ${ }^{30}$ Susette Mariboe skrev derefter et andragende til kongen om støtte, men heller ikke det kom der noget ud af, skønt hun forsøgte at fremme sagen ved en audiens. ${ }^{31}$

Men Susette Mariboes kreds var ordholdende, og den 30. oktober 1878 flyttede Elise Lindberg fra Moltesens og til en lejlighed, hun havde lejet i Ottersbøl mølle ved Mjolden. Hun kunne nu åbne sit hjem for unge piger.

\section{»Hemmet« i Ottersbøl mølle}

Den første elev, Dorte Dall fra Københoved, flyttede ind den 1.november. Hun var gårdmandsdatter, 34 år gammel, havde lært skræddersyning og drev sypigevirksomhed fra barndomshjemmet. Hun ejede en del penge, »men havde meget at lære« rent bogligt. En ugestid senere kom Kirstine Kristensen, 26 år gammel og fra Salling. Hun var stuepige hos en gårdmand i Hygum, som ønskede, at hun skulle blive lærerinde for hans børn. Men først skulle hun uddannes et halvt års tid. Desværre havde det dog sine vanskeligheder, da hun var "meget ringe begavet og knap kunne tælle til 5«. Begge pigerne havde opholdt sig i Sønderjylland i flere år og været på et par højskoler. Den tredje elev, Elisabeth Klausen fra Højrup ved Toftlund, var 26 år gammel og havde gået på Rødding Højskole. Hun flyttede ind omkring den 1.december. Hun var stuepige hos en gårdmand i Arnum og skulle også være dansk privatlærerinde dér i det skjulte. Hun var meget dygtig til alt undtagen tysk. ${ }^{32}$

Straks i det nye år aflagde en tysk gendarm uanmeldt besøg i møllen og spurgte, om der holdtes skole. Elise Lindberg svarede nej, hun havde blot de tre $\mathrm{i}$ huset for at undervise dem $\mathrm{i}$ håndarbejde og huslige sager. Gendarmen bad om deres navne og spurgte, hvor de var født. Da han var gået, foreslog hun pigerne, at de hver skulle sy en lille bog og skrive »den finere madlavning" udenpå. Deri skulle skrives diktat efter kogebogen, og de lagde straks ud med "Forloren Skildpadde Suppe«. Få dage senere mødte skoleråden op medbringende en skrivelse, hvorefter hun skulle mulkteres, fordi hun havde undladt af melde afgang fra Randerup og tilgang i Ottersbøl. Hun nægtede at betale og blev stævnet til at give møde for herredsfoged Grünfeldt i Tønder.

Det var med bange anelser, hun mødte op hos herredsfogden. Kort tid forinden havde Elise Stampe nemlig sendt et åbent brevkort, hvori hun omtalte skolen og ønskede hende flere elever. Elise Lindberg frygtede udvisning.

Ved samtalen foreholdt Grünfeldt hende, at det var meldt, at hun holdt højskole, og da hun var dansk statsborger, skulle han kende hendes »Un- 


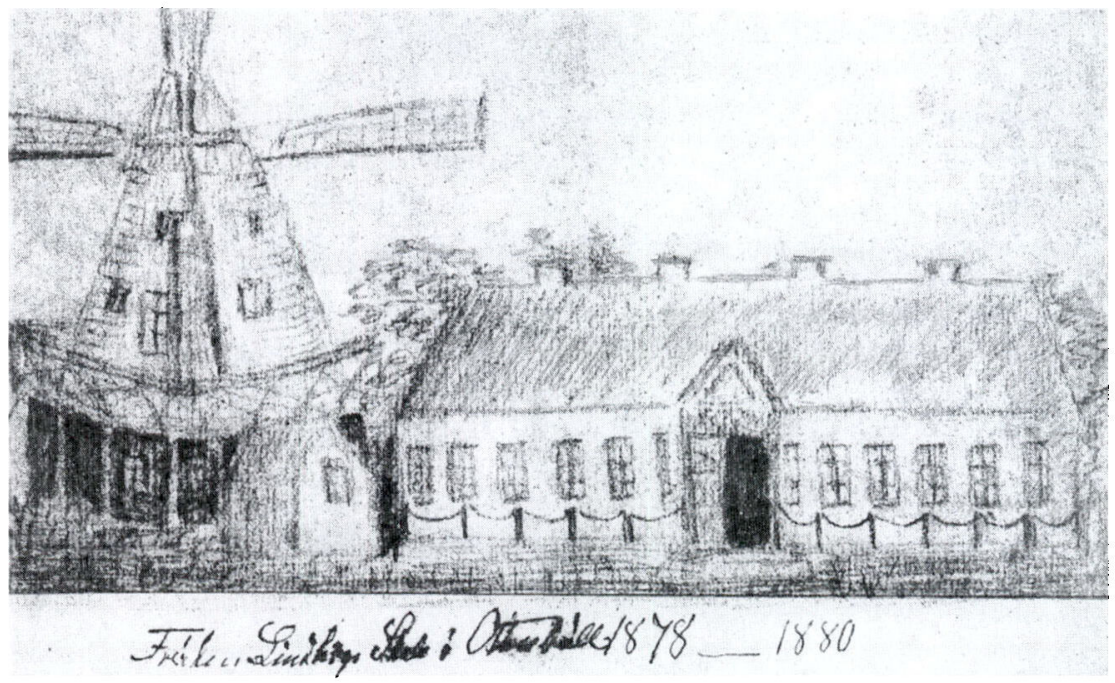

Med sit tegnetalent kunne Elise Lindberg hojt op i ärene fastholde erindringen om de steder, hun havde virket. Her Ottersbol molle, en fordringsles blyantstegning, fundet blandt gamle familiepapirer. Institut for Sonderjysk Lokalhistorie.

dersaatlige Forhold«. Hun fastholdt, at hun, ligesom det var skik i mange præstegårde, blot havde tre unge piger $\mathrm{i}$ huset et årstid for at oplære dem $\mathrm{i}$ huslighed, sundhedslære, lidt sygepleje, håndarbejde, tysk, verdenshistorie og geografi samt »hvad der hører med til almindelig Dannelse«. Betalingen var ansat lavest muligt ligesom i højskolerne. Grünfeldt var tilfreds med svaret og nedskrev hendes erklæring, som hun underskrev. Mere skete der ikke.

I april 1879 skrev Monrad og spurgte, hvordan det gik, "navnlig med Hensyn til Bekostningerne« ved forehavendet. Han havde troet, at alt var i orden, men efter sin seneste samtale med Susette Mariboe var han kommet i tvivl. ${ }^{33}$

Hans tvivl var ikke ubegrundet. Der var kun kommet én elev mere, så det var svært at få økonomien til at hænge sammen, selv med pengene fra København. Lejligheden kostede $180 \mathrm{kr}$. om året, og da den bestod af dagligstue og spisestue, hver på to fag, en sal på fire fag, hendes eget soveværelse samt et kammer på et fag, bryggers og køkken, havde hun kalkuleret med seks piger ad gangen.

\section{Visby}

April 1880 flyttede Elise Lindberg igen. Møllen skulle sælges, og den nye ejer ville ikke forny lejemålet. Hun overvejede at købe det tidligere tinghus i Visby, 


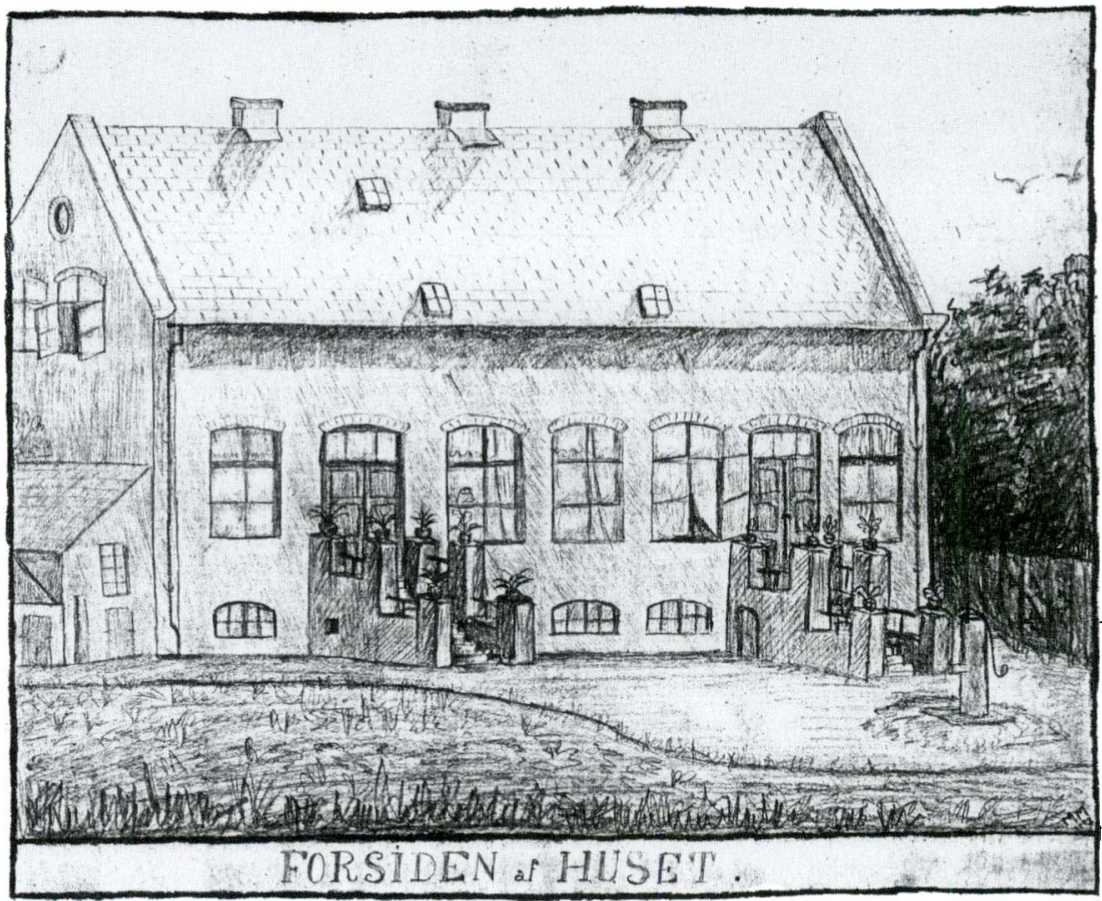

Froken Lindbergs skole i Vishy. Tegning i hendes arkiv i Det kongelige Bibliotek.

som var til salg, men lejede i første omgang en lejlighed, der var lidt større end den i møllen og til samme husleje.

I Visby var der seks elever fra den første dag, og mod slutningen af 1881 gik det tilsyneladende godt. I hvert fald købte Elise Lindberg tinghuset den 11. december for $12.000 \mathrm{kr}$. Hun havde ganske vist ikke selv penge nok, men kredsen i København trådte til. Susette Mariboe gik tiggergang, og baronesse Wedel og Marie Meinert lånte hende hver en sum, rentefrit og med lang frist, ${ }^{34}$ og hun tog så tillige et lån $\mathrm{i}$ den lokale sparekasse. De $1200 \mathrm{kr}$. årligt fra København var dog stadig nødvendige, ligesom den hjælp Monrad ydede gennem Komiteen ved at sende bøger til rimelige penge, oftest som gave. I 1882 sendte Monrad tillige det glædelige budskab, at han fra nu af kunne sende 360 kr. årligt, "svarende til Betalingen for en Friplads i Deres Kostskole, når De er så venlig at meddele mig, hvem De bestemmer skal nyde den og fra hvad Tid «. ${ }^{35}$

Præcis hvilke bøger Elise Lindberg anvendte ved undervisningen meddeler erindringerne ikke noget om, men en liste over »Bøger der stå til Rådighed «, som Monrad sendte hende den 12. juli 1880, giver et indtryk af, hvilke titler 


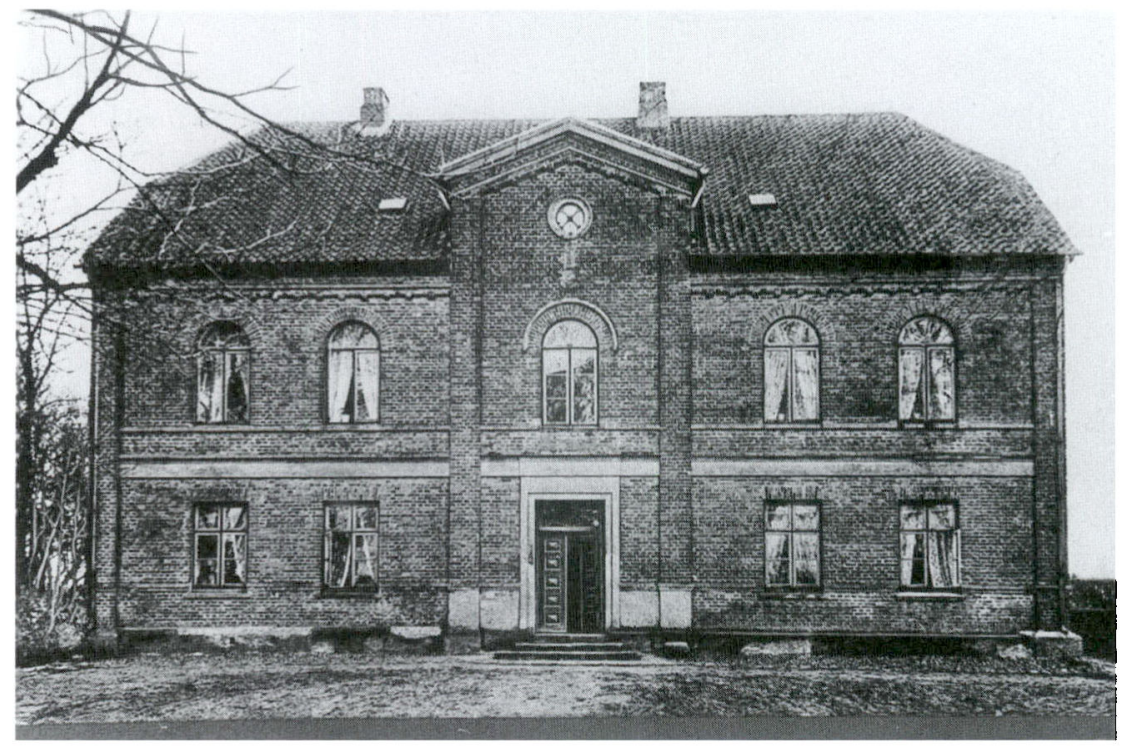

Tinghuset $i$ Visby, hvor frk. Lindherg indrettede skole i 1880. Foto: Institut for sonderjysk Lokalhistorie.

hun kunne rekvirere "til god dansk Læsnings Udbredelse i Sønderjylland «. Det var f.eks. Billeder af Dyrelivet og Dyrenes Liv af Sahlers. Petersens Vore Sangfugle. Internationale, Gustav Adolf samt Danmark 1848 af Rosenberg. Ingerslevs Nero samt Jerusalems Ødelæggelse. Vaupells Fredericiaslaget og Slaget ved Isted. Thriges Perserkrigene, Den franske Revolution og Korstogene. Steenstrups Englands Erobring og Lefoliis Egils Saga. Naturligvis også Grundtvigs Kirkelig og folkelig Digtning, Brochmanns Mod Papismen og Danske Ordsprog af Rasmussen. Af Holberg Jeppe på Bjerget, Barselstuen, Erasmus Montanus m.fl. Oehlenschlägers Barndom og Ungdom. Af Thyregod bl.a. Rasmus og Ingeborg, Maren Avlskarl, To Forskelle, Mosekongen, Præstens Plejedatter og Selvejer og Fæstebonde. At Hammerichs Thorvaldsen og hans Kunst står opført lige under Dickens Juleæventyr viser, hvor varieret udbudet var. Listen omfatter desuden Husvennen, Familievennen samt et par børneblade. ${ }^{36}$

\section{Udvisning 1884}

Efteråret 1884 sluttede det sidste kapitel af Elise Lindbergs liv i Sønderjylland. I februar måned samme år havde en af de dansksindede i Sommersted bedt 
hende om at opfordre unge piger fra vestkysten til at deltage i en fælles tur til København tidligt på sommeren. Det drejede sig om en demonstration til fordel for det danske i Slesvig. 300 unge sønderjyske piger skulle præsenteres for »det lattermilde unge København«, og Holger Drachmanns »Enker er de sønderjydske Piger« skulle afsynges nogle gange. Hun blev opfordret til at deltage, men sagde nej. I slutningen af juli skulle en lignende fest finde sted i Varde, og den lokale festkomites formand, doktor Kietz, havde indbudt hende til at være familiens gæst. At hun igen sagde nej blev opfattet som udtryk for manglende nationalfølelse, og hun følte sig presset til at deltage. Da hun ankom, måtte hun som gast hos doktor Kietz sammen med ham og hans kone "gaa i Spidsen - og der var efter sigende 200 tyske Spioner tilstede«. Fra Varde rejste hun direkte til det årlige lærermøde i Askov og hørte dér, at flere sønderjyske gårdmænd og skolelærere, hvis koner havde deltaget i demonstrationen, var blevet udvist.

Den 29. september blev Elise Lindberg stæunet til at give møde for herredsfogden i Tønder. Ved mødet skete det, hun længe havde frygtet: hun blev udvist. Da hun spurgte om årsagen, lød svaret: "Regeringen giver ingen grund «. Nogle dage senere blev skolebygningen i Visby konfiskeret af de tyske myndigheder. Godt 100 voksne elever havde da siden 1878 nydt godt af hendes undervisning. 32 af dem virkede som privatlærerinder i Slesvig.

Elise Lindberg flyttede derefter over grænsen og lejede Søgård Højskole ved Vamdrup, hvor hun den 7. oktober åbnede Frøken Lindbergs udvidede Skole på Søgård. Formålet var som hidtil at uddanne unge kvinder til privatlærerindegerningen i dansksindede hjem syd for grænsen.

\section{Frøken Lindbergs udvidede Skole på Søgård}

„Ja, kære Frøken Lindberg«, skrev Monrad den 12. oktober 1884, »det var jo et nyt Slag, at nu også De måtte vige Pladsen. Det er jo heldigt, at De strax har kunnet få en ny Lejlighed, hvor De jo ganske vist mere uforstyrret kan udføre Deres Gerning. Men jeg frygter, at der herefter vil blive lagt de Piger, der ere uddannede hos Dem, særlige Vanskeligheder i Vejen her nede - enhver Lærerinde, selv i private Familier, skal jo gøre Regnskab for, hvor hun er uddannet ${ }^{37}$

Skolen på Søgård var delt $\mathrm{i}$ to afdelinger, en sprogafdeling og en højskoleafdeling, som dog havde fælles grundfag. Eleverne i højskoleafdelingen havde ingen sprogtimer, mens eleverne $\mathrm{i}$ sprogafdelingen frit kunne vælge, hvilke sprog de ønskede at lære. Der var afsat otte ugentlige timer til grammatik, oplæsning, stile og samtale, det sidstnævnte for at opøve elevernes talefærdig- 
hed $\mathrm{i}$ fremmedsprog. Elise Lindberg havde nu andre lærere til hjælp, nemlig frk. K. Finnemann, som tidligere havde været lærerinde i Sønderjylland samt en lærer Møller fra Øster Vamdrup som timelærer. ${ }^{38}$

Men problemerne viste sig snart. Der kom kun få elever. Det første år sytten, året efter elleve, året efter igen atten, og ingen af dem var der længere end nogle få måneder. Hun gjorde ellers hele tiden en indsats for at trække elever til. Lod i 1885 trykke et skoleprogram på fire sider, som uddeltes til interesserede gennem Komitéen og bl.a. Schrøder, og deltog i 1888 i $» D e n$ store nordiske Udstilling« i København med elevarbejder - tegninger, træarbejder og oliemalerier - som fik rosende omtale.

Da Mathias Steenstrup, ministeriets tilsynsførende ved folkehøjskolerne, i november 1885 skrev betænkning om støtteandragender for finansåret 1885/ 86, kommenterede han skolen således: "Ved mit Besøg her i Sommer fik jeg det Indtryk, som ogsaa svarer til det almindelige Omdømme, at Frk. Lindberg er en karakterfast Personlighed, der med Klarhed og Kraft forfølger sit Formaal at give de unge Piger en dygtig Undervisning i de forskjellige Fag, saa at de kunne optræde som Lærerinder i Familier. Undervisning i levende Sprog, navnlig Tysk, spillede her en særegen Rolle af Hensyn til, at Eleverne skulle kunne bruges som Lærerinder i Sønderjylland. Det er vel ikke nogen stor Mængde af Lærerinder, som Frk. Lindberg har uddannet for Sønderjylland, men alligevel tør man maaske nok tillægge dem en vis Betydning i den nuværende Kulturkamp, hvilket er medvirkende til, at hun ikke kan opnaa særlig stor statsstøtte ... ${ }^{39}{ }^{39} \mathrm{Han}$ anbefalede $800 \mathrm{kr}$. i tilskud, året efter faldt det til $700 \mathrm{kr}$.

Den 31.oktober 1888 lukkede skolen på Søgård. Der var ikke indmeldt et tilstrækkeligt antal elever. ${ }^{40}$

\section{De evindelige pengesorger}

Livet igennem plagedes Elise Lindberg af økonomiske problemer. Det var som en byrde, hun slæbte med fra barndomshjemmet, og som hun ikke kunne komme af med. Da hun rejste til Sønderjylland, havde hun $200 \mathrm{kr}$. årligt af bibelpengene. Lønnen som privatlærerinde i Sønderjylland var ikke stor, hos Brodersens arbejdede hun endda uden løn i mere end et halvt år. Bibelpengene mistede hun i 1875 eller 1876 ved forlæggerens fallit, men Monrad trådte til og sørgede for, at det beløb, som hun gennem Schrøder fik fra Foreningen "Dannebrog«, blev forhøjet til $300 \mathrm{kr}$.

Indtil 1878 var hun endnu nogenlunde økonomisk uafhængig, hvilket hun betragtede som en betingelse for kunne arbejde syd for grænsen. Takket være 
pengene fra "Dannebrog« havde hun lidt stående i Diskontobanken i Ribe. ${ }^{41}$ Men da hun realiserede drømmen om et hjem for unge piger, blev hun stadig mere afhængig af sit netværk. Lånene til huskøbet i Visby blev eftergivet hende, »hverken Marie Meinert eller Baronese Wedel fortryder det Offer, de har lagt paa Sønderjyllands Alter; det blev givet af Fædrelands Kjærlighed og med Haabet om at gavne Sagen «, skrev Susette Mariboe i oktober 1888, da tanken om de mange penge, der var gået tabt, plagede Elise Lindberg. ${ }^{42}$

Med årene blev det stadig vanskeligere for Susette Mariboe at indsamle de lovede $1200 \mathrm{kr}$. Beløbet skrumpede vistnok ind til det halve allerede i 1885 . Susette Mariboe skrev da, at hun havde fået $100 \mathrm{kr}$. hos baronesse Wedell, og at hun lange ikke havde set Marie Mejnert. Selv kunne hun ikke mere yde noget bidrag, da hun ikke tjente noget: »Min Pension er jo meget lille«, fortsætter hun, "saa det er kun ved at slaa mig sammen med Skovgaards, at jeg kan føre Huset, som det nu gaar. Nogle af de gamle Venner er jo døde, nogle udtraadte fordi de mene at De kan faa Højskolehjælp; igjennemgaaende har det gjort en stor Forandring, at Skolen ikke mere er i Sønderjylland. Jeg kan derfor endnu ikke sige Dem, hvormeget jeg kan sende Deres Skole ... «. ${ }^{43}$ Herefter blev der løbende sendt småbeløb.

Heller ikke skolen i Søgård hvilede i sig selv. Statstilskuddene var som tidligere omtalt ikke store. Amtet ydede første gang støtte skoleåret 1887-88, men da var det for sent. ${ }^{44}$

Da skolen i Søgård lukkede, stod Elise Lindberg uden en øre. "Vi sender Dem derfor disse 100 Kroner foreløbig, og til Terminen paatage vi os at betale Huslejen til Lærer Brammer paa Amager«, skrev Susette Mariboe, »og saa haabe vi igjen senere at faa sendt lidt mere ${ }^{45}$

\section{En afslutning i Kolding}

»Idet jeg takker for Deres idag modtagne Brev, vil jeg tillade mig at omtale hvad jeg for Fremtiden har isinde at gøre, og udbede mig deres ærede Svar paa et Par Spørgsmaal«, skrev Elise Lindberg den 3.marts 1889 til Ludvig Feilberg, ministeriets nye førstemand ved Tilsynet med folkehøjskolerne. "Skolen paa Søgaard er afsluttet, og kan aldrig genoptages, dels fordi en saadan Skole ikke kan gaa paa denne Egn, dels fordi Ejendommen er solgt til en Bonde, der tiltræde den til 1. April. Da jeg i Efteraaret var langvarig syg og maatte afgive Skolen, søgte jeg Pension, og har af Regering og Rigsdag erholdt en lille aarlig Understøttelse. Min Hensigt med at flytte til Kolding er nu at optage unge Sønderjydske Piger i mit lille Hjem og give dem den samme Undervisning i alle de danske Fag, som jeg altid selv har gjort her paa Skolen«. 


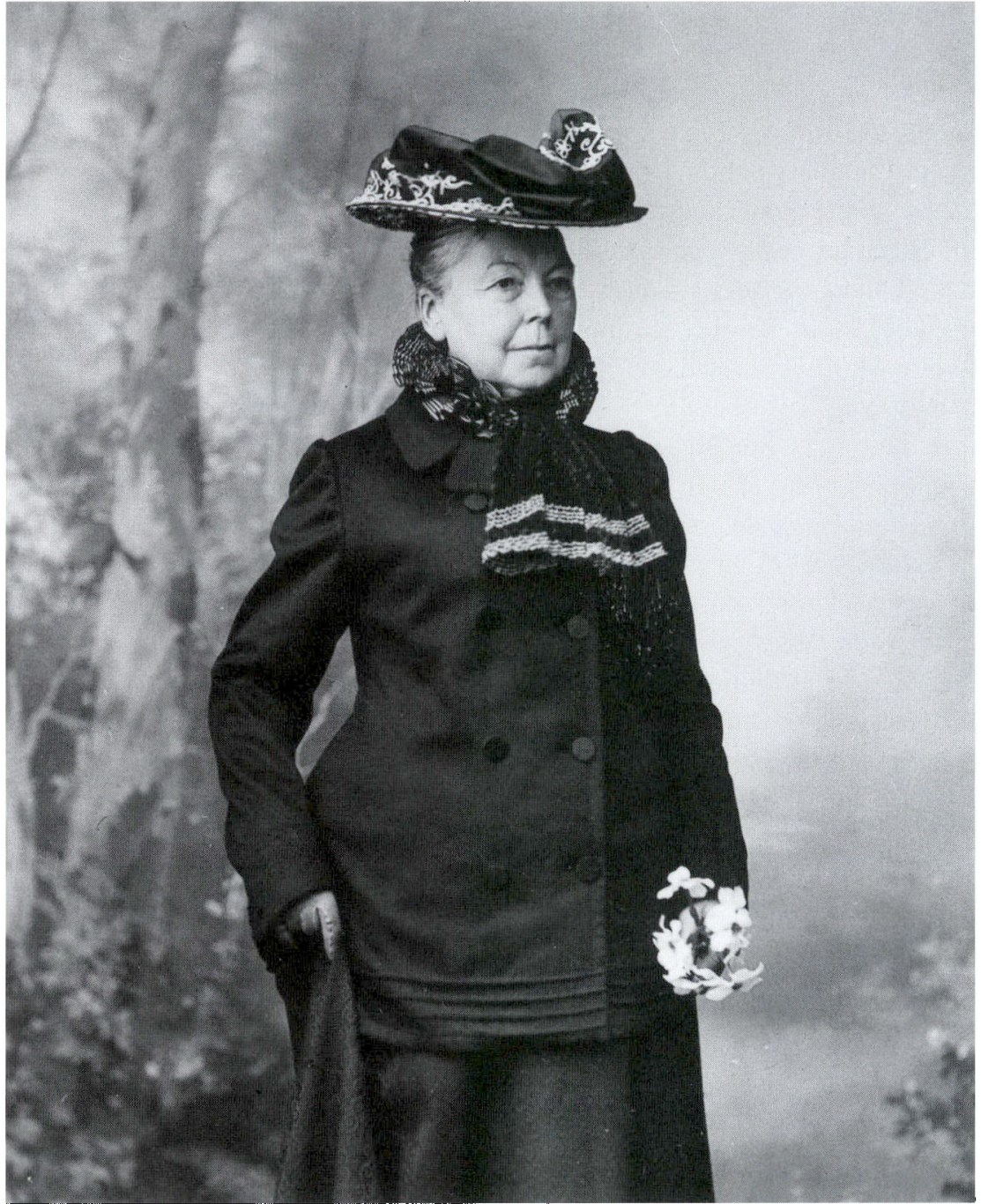

Elise Lindberg som aldre. Foto: Det kongelige Bibliotek.

Hun spørger Feilberg, om hun kan få statsstøtte, men samtidig oppebære pensionen; den vil hun ikke sætte over styr. Hun kan højst have tre elever i skolen. ${ }^{46}$ Feilberg svarede, at hun ikke behøvede at gøre sig spekulationer om retten til at oppebære både pension og statstilskud, da hun under ingen omstændigheder kunne opnå støtte til en skole, som den omtalte; den var for lille. ${ }^{47}$ 
Det blev ikke nogen stor skolevirksomhed, Elise Lindberg iværksatte i lejligheden på hjørnet af Laadigport og Hospitalsgade. Da hun nedskrev »Oplevelser « i 1899 havde blot femten unge piger modtaget undervisning i tegning og maling hos hende, men skolen blev et kærkomment tilskud til den pension, som hun ved venners hjælp havde fået tilkendt fra staten. ${ }^{48}$

Den 13. oktober 1889 fik hun besked om Susette Mariboes død dagen før. Brevet kom fra Nanny Bech. Hvad Elise Lindberg senere skrev til Nanny Bech, står hen i det uvisse, men hun beklagede sig uden tvivl. I december sendte Nanny Bech hende en julehilsen, håbede at det snart måtte gå nogenlunde efter ønske med elever og indtægter og fortsatte: »Jeg har i Opbevaring lidt Penge, som er bestemt til Dem. Susette Mariboe mente altid at de skulle gjemmes, til De engang særlig havde en Nødskilling Behov, for hun vidste med Sikkerhed, at der ikke vilde kunde indsamles mere, og det var ligesom om hun ømmede sig ved at give det sidste bort; dog nu er De jo Herre over det, og siger mig nok Besked, det er maaske ikke værdt at vente paa Sygdom, eller uventede Tilfælde ... Min Søster Molly sender Dem venligst Hilsen, det gør ogsaa Moltkes, gamle Marie Meinert og Marie Møller....$^{49}$ Hvormange penge Susette Mariboe havde gemt, oplyser hverken Nanny Bech eller Elise Lindberg, men pengene faldt på et tørt sted.

\section{Nødvendighed eller kald?}

Elise Lindberg var siden sin tidligste ungdom engageret i samfundsanliggender, og det var kun naturligt $i$ betragtning af hendes baggrund og familiens omgangskreds. Det er imidlertid usikkert, om hun i sine yngre år for alvor havde ønsker om at bedrive folkelig oplysningsningsvirksomhed. Måske var det snarere broderens giftermål med en, hun ikke brød sig om, der fik hende til at påtage sig lærerindegerningen. Da hun måtte forlade Jens' og Amalies hus for at stå på egne ben, voksede hun imidlertid med opgaven og kom til at holde af den.

Med årene lærte hun at optræde stadig mere taktisk klogt $\mathrm{i}$ forhold til den sag, hun kom til at arbejde for. I de år hun opholdt sig i Nordslesvig, deltog hun i et væld af politiske sammenkomster: Vennemøder, møder i Komiteen, møder til fordel for søndagsskoler og husflidsforeninger. Hun agiterede ved enhver lejlighed $-i$ begyndelsen gennem Morad fordi hun ikke selv havde mod til at tale i forsamlinger - for, at dansksindede familier skulle lade deres børn undervise privat af danske lærerinder, for derigennem ville danskheden holdes levende syd for grænsen. Hun påtog sig at skaffe danske lærerinder gennem sit omfattende netværk, især gennem Ludvig Schrøder i Askov og Jens Nørre- 
gård på Testrup Højskole, ligesom hun også skaffede tjenestepladser til karle og piger på begge sider af grænsen.

Mærkeligt nok var hun ikke i kontakt med Natalie Zahle og dennes elev Marie Kruse, to af tidens fremtrædende kvinder med relation til det sønderjyske spørgsmål. Men det skyldtes måske, at hun i begyndelsen ikke levede op til Natalie Zahles idealforestillinger om en lærerinde: at hun skulle føle kærlighed til »sit Kald«, have valgt det for dets egen skyld, og ikke fordi hun stod uden andre forsørgelsesmuligheder. ${ }^{50}$

Hendes engagement $\mathrm{i}$ kvindesagen er vanskeligere at få øje på, og det kom $i$ hvert fald sent. Erindringen om faderens afvisning, da hun i sin tid spurgte, om hun måtte studere hos frøken Zahle, kan måske bedømmes som efterrationalisering. I bogen »Victoria«, en nøgleroman som hun skrev og selv bekostede udgivet i 1889, regner hovedpersonen Victoria sig da heller ikke blandt de emanciperede. ${ }^{51}$ Andet peger imidlertid også på, at kvindesagen ikke helt var god tone i Elise Lindbergs kreds.

I 1887 meldte hun sig ind i Dansk Kvindesamfund og agiterede samme år for, at danske kvinder skulle udvandre til Amerika. ${ }^{52}$ Dér var der brug for kvinder, dér havde de mulighed for at få arbejde modsat her, og samtidig kunne de så udrette noget for Danmark. I august måned 1887 skrev hun en engageret artikel i Højskolebladet, ${ }^{53}$ og senere på året fulgte hun sagen op i dagspressen. Men det faldt ikke i god jord hos hendes nærmeste støtter. Susette Mariboe skrev til hende, at hun havde fulgt skriverierne i Morgenbladet, »skjønt jeg ikke helt kan dele Deres Anskuelse i dette Spørgsmaal, jeg har intet imod at Kvinder udvandre, som have Lyst og Evne dertil, men en systematisk Udvandring synes jeg ikke at kunne forstaa at være tilraadelig, trods de 65000 , som vi dog ikke kunne sige staa ledige paa Torvet ... ${ }^{54}$

Ludvig Schrøder i Askov tilkendegav sin mening på anden vis. »Kjære Charlotte«, skrev Kirstine Frederiksen, formand for Dansk Kvindesamfund, til hans kone på Samfundets papir; "Kunde det ikke være fornuftigt, at Elise Lindberg kommer til Amerika? Hun ser ganske vist umuligt paa den Sag med Udvandring, men hun er begejstret for den, er vel ogsaa et saa energisk Menneske, at hun vilde kunde udrette noget - thi ogsaa jeg tror, at der kan udrettes noget - og vilde maaske komme til en sand Opfattelse af Sagen ved at komme derover. Kunne hun ikke repræsentere Højskolen ved Kongressen? ... «. ${ }^{55}$ Elise Lindberg kom ikke til Amerika. ${ }^{56}$

I den undervisningsvirksomhed Elise Lindberg bedrev i godt og vel tredive år, underviste hun ud fra grundtvigske idéer, som ikke gik ud på pegepind og udenadslære, og som lagde vægt på, hvad der tjente nationalsagen bedst. Hvert eneste år deltog hun i det årlige lærermøde på Askov, hvor nye skoletanker og nye pædagogiske idéer udveksledes. Hele livet lærte hun for selv at blive dygti- 
gere til at lære andre. At hun voksede med gerningen fremgår måske klarest af et brev, som Georgia La Cour Pedersen, højskolemor i Rødding, skrev til Charlotte Schrøder: "... Ja, så var det Elise Lindberg, som jeg så igjen fik et Møde med, og det slog mig straks, hvor hårdt jeg havde omtalt hende den Dag til Dem... Jeg fik et godt Indtryk af hende, og synes jeg kom til at mærke, at hun virkelig har optaget en god Gjerning og er kommen her ned for at gjøre Gavn, ellers kunde hun ikke stå så frejdigt nu efter så mange Skuffelser. Jeg synes ikke før jeg har seet hende så oplivet og så rede til at gjøre noget for andre, så jeg kom til at tænke, at hun dog vist nu har fået Brug for sine Kræfter og Evner, og at det at give sig hen til en god Gjerning her som altid fører sin Velsignelse med sig, så hvordan og efter hvor stor en Målestok hun kan giøre det, er det ikke andres Sag at bedømme, og det gjorde mig ondt, at jeg havde kritiseret hendes Færd .... ${ }^{57}$

Den københavnske støttekreds havde en betydning, som ikke må glemmes. Det var et vigtigt led i hendes styrke og havde stor betydning som økonomisk sikkerhedsnet at hun gennem breve og besøg forstod at fastholde og udbygge det netværk, hun havde fra barndomshjemmet. Uden netværket ville hun ikke have kunnet udrette det hun nåede. ${ }^{58}$

Elise Lindberg boede sine sidste år i Kolding. Her havde flere af vennerne fra arbejdet med den nationale sag slået sig ned, da de trak sig tilbage. I denne kreds tilbragte hun sine sidste år. Hun døde i 1913.

\section{FORKORTELSER}

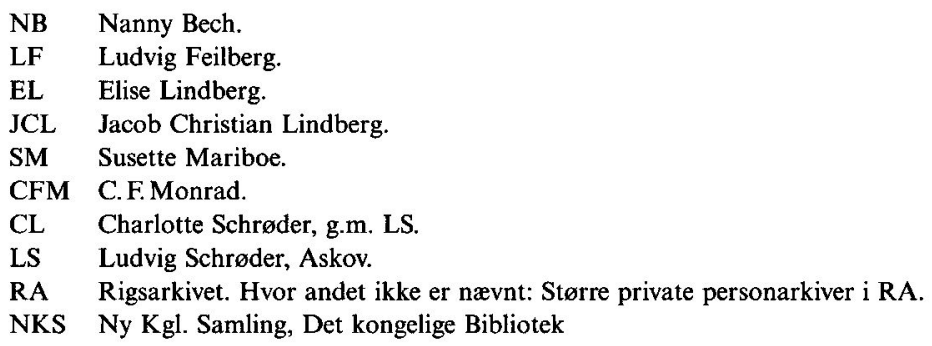

NOTER

1. Brev fra J. C. Lindberg til søsteren Elise Alberti, gengivet efter Højskolebladet 1897, s. $75 f$.

2. Elise Lindbergs arkiv beror i RA, Større private personarkiver no. 5887 , og omfatter i alt 3 pakker. To pakker indeholder breve til EL, én de håndskrevne: Oplevelser nedskrevne af Elise Lindberg. 1899. Kolding, Oplevelser fra 1872-73 og Elise Lindberg Randrup 1875, Optegnelser fra Oktober 1872 og fremdeles under mit Ophold i Sønderjylland, Sønderjylland 1878, Visby 1881, et læg betegnet Søgaard Kostskole 1884-88 og indeholdende tryksager m.v. samt et par 
læg med forskelligt. Ved udarbejdelsen af artiklen har brevene og optegnelserne haft første prioritet som kilde, erindringerne anden. Der henvises kun undtagelsesvist til erindringer og optegnelser. Se vedr. EL endvidere: Børge L. Barløse: En grundtvigsk skolegerning i Vestslesvig i SJy MSkr 1977 s. 114-117; K. Schmidt Nielsen: Visby forsamlingshus, i SJy MSkr 1995 s. 88-89. Disse to artikler indgår ikke i afhandlingens kildemateriale.

3. 1797-1857, se også Dansk Biografisk Leksikon; F: res. kap. i Ribe Domkirke og sognepræst i Seem Niels L. (1758-1830) og Anna Magdalene Jacobsdatter (1766-1840).

4. 1805-1866. F: destillatør og brændevinsbrænder Jens Peter Hansen Thoyring og Elise Christiane Jørgensen (g. $2^{\circ} 1817$ med kontrollør Simon Simonsen).

5. Kaj Baagø: Magister Jacob Christian Lindberg. 1958, s. 19-54.

6. Anna og Ferdinand. De fire ældste børn var Jens, Niels, Elise og Johan.

7. Kaj Baagø. 1958, s. $286 \mathrm{ff}$.

8. Kaj Baagø. 1958, s. 360f.

9. Det må være de såkaldte Regenburgske sprogreskripter af 1851, EL omtaler. De blev udfærdiget af Th. A.J. Regenburg, mens C. Moltke var slesvigsk minister, og bestemte, at undervisningssproget $\mathrm{i}$ de blandede distrikters almue- og borgerskoler skulle være dansk, jf. H. Hjelholt: Den danske sprogordning og det danske sprogstyre i Slesvig mellem krigene (1860-1864). 1923 og L.S. Ravn: Trak af folkeskolens historie i Nordslesvig 1864-1920. 1981.

10. Albertine Sophie Frederikke og Carl Alberti (jurist og politiker).

11. Ferdinand boede ikke hjemme, Johan døde af tyfus 1853 .

12. Anna døde 1858.

13. NKS 3550. 13.12.1871 EL til LS.

14. NKS 3550. 13.12.1871 EL til LS.

15. NKS 3550. 31.12,1871 EL til LS; henv. kan skyldes, at LS og Niels L. stod på venskabelig fod, jf. breve i NKS 3550; Niels L. redigerede Kirketidende, som LS skrev til.

16. RA 5887. 29.9.1872 LS til EL (M. Rosendals breve til LS).

17. Joakim Larsen: Bidrag til Den danske Skoles Historie 1818-1898. 1984/1899 s. 264; i forfatterens upubl. mat. findes eksempler på $50 \mathrm{kr}$. årlig plus bolig og brændsel.

18. RA 5887. 26.2.1872 LS til EL (M.Rosendals brev til LS).

19. NKS 3550. 1.4.1872 EL til LS.

20a.Bendix Conrad Heinrich Andersen v. Nutzhorn (1833-1925), komponist og lærer ved Askov Folkehøjskole.

20. NKS 3550. 21.11.1872 EL til LS.

21. NKS 3550. 25.5.1873; seminarist P. Thomsen, Ryslinge højskole 1867-1902, jf. H. Rosendal: Danmarks Folkehøjskoler og Landbrugsskoler. 1894.

22. NKS 3550. 25.5.1873 EL til LS.

23. NKS 3550. 27.11.1873 EL til LS; »faders sang« er jf. et brev fra EL til Nutzhorn, Askov, en sang, som Grundtvig skrev til JCL. Der er uden tvivl tale om "Vi saae en vældig Stridsmand ...«, som blev skrevet til afsyngelse ved afsløringen af det monument, der rejstes for JCL i Skibelund krat 3.11.1869 jf. Steen Johansen: Bibl. over N. F. S.Grundtvigs Skrifter 1850-1871. I-III. 1952, bd. III, s. 334 .

24. Hans Chr. Thiessen, præst i Randrup 1872-1874 (1884), var tysksindet.

25. RA 5887. C-2 (Randrup 1875).

26. NKS 3550. 17.6.1878 EL til LS og CS.

27. L. S. Ravn. 1981, s. 14, s. 23, s. 38, s. 46f., s. 51 f.

28. RA 5887. 3.2.1878 CFM til EL; skolen solgtes til frk. Amanda Boldt, som selv havde en skole. De to skoler videreførtes i CFMs skoles lokaler.

29. RA 5887. 4.6.1878 CFM til EL.

30. RA 5887. 4.7.1878 CFM til EL.

31. RA 5887. 6.8.1878 SM til EL.

32. Strategien blev almindelig, da muligheden for at holde dansk skole ophørte, jf. Bernh. Hansen: I Fædres Spor. 1945, s. 152.

33. RA 5887. 19.4.1879 CFM til EL. 
34. RA 5887. 15.7. u.å., 25.10.1888 SM til EL.

35. RA 5887. 6.6.1882 CFM til EL; Komitéen bestod af Jens Nørregård, Mørk-Hansen og J. Johansen, som dannede Fore. til det danske Sprogs Bevarelse i Nordslesvig. Efter at CFM afhændede skolen i Flensborg, stod han for uddeling af bøger til undervisningsbrug til lærerinder, der arbejdede for sagen. Midler til forehavendet skaffedes gennem frivillige bidrag.

36. RA 5887.

37. RA 5887. 12.10.1884 CFM til EL.

38. RA Kultusmin. 2.kt. Andragender om tilskud til folkehøjskoler og landbrugsskoler 1884/85 (06/ 24506).

39. Som note 38.

40. NKS 4573. 24.2.1889 EL til LF.

41. Jf. div. breve fra CFM og SM. SM skriver altid, at hun sender så og så mange penge til "Deres Kusine i Ribe«.

42. RA 5887. 25.10.1888 SM til EL.

43. RA 5887. fra SM u.å., men er fra $1885 \mathrm{jf}$. EL til LS 23.5.1885.

44. RA 5887. 15.12.1888 fra Ribe Stiftamt om tilskud på 1.800 kr.

45. RA 5887: 17.11.1888 SM til EL.

46. NKS 4573. 3.3.1889 EL til LF.

47. RA 5887. LF til EL, jf. koncept på bagsiden af et brev 8.3.1889 EL til LF.

48. RA 5887. 17.11.1888, 29.12.1888 SM til EL, 5.2.1889 NB til EL; pensionen var på $600 \mathrm{kr}$. årligt.

49. RA 5887. 13.10.1889, 21.12.1889 NB til EL.

50. Birgitte Possing: Viljens Styrke. 1992, s. 123.

51. Pil Dahlerup: Det moderne gennembruds kvinder. Paperback-udgaven, 1983, s. 346 og 544. "Victoria" stemmer dog ikke overens med „Optegnelser«. Bogen blev i øvrigt forsøgt solgt gennem nogle højskoler, jf. RA 6454: EL til ET 1889, 1890, 1891.

52. Venligst oplyst af Kvindehistorisk Samling.

53. Nr. 33. "Et Par Ord til Overvejelse."

54. RA 5887. 19.12.1887 SM til EL.

55. NKS 3550. 20.11.1887 Kirstine Frederiksen til CS.

56. CSs svar kendes ikke, da der desværre for mange år siden er sorteret med hård hånd i Dansk Kvindesamfunds arkiv, og Kirstine Frederiksen ikke har efterladt sig papirer. Breve fra/til EL/ LS foreligger ikke efter nov. 1887.

57. NKS 3550. 6.1.1872 Georgia La Cour Pedersen til CS.

58. Mange havde i årenes løb givet deres bidrag til de $1200 \mathrm{kr}$. årligt, som Susette Mariboe indsamlede på kredsens vegne. EL fik dog først kendskab til deres navne, da SM ved juletid 1887 sendte hende $130 \mathrm{kr}$. fra pastor Beck og beklagede den beskedne sum og vedlagde "Listen over dem, som have bidraget til Deres Skole fra Aaret 1878, jeg tænkte det maaske vilde more Dem deriblandt at finde flere kjendte Navne, en Del ere jo døde, og en Del ere faldne fra, der er jo mange Krav paa Folks Penge i vor Tid ...k. - Listen: Baronesse Elise Stampe, Baron Henrik Stampe, Baron Holger Stampe, Baronesse E. Vedel, Frøken Scavenius, Kammerherre Scavenius, Fru Helga Jørgensen, Frøken K. Rosenørn, Pastor Peter Rørdam, Pastor Brandt, Pastor Ingerslev, Pastor Hohlenberg, Pastor Berg, Fru Mejnert, Frøken Marie Mejnert. Frøken Helene Mejnert, Frøken Nanna Mejnert, Herredsfoged Mejnert, Fru E. Holm, Frøken E. Holm, Fru Lauritzen, Candidat Gøriche, Brygger Vestberg, Fru Vestberg, Hr. N. F. Larsen, Hr. H. K. Larsen, Hr. F. Larsen, Fru Ida Larsen, Fru A. Nissen, Hr. Carl Larsen, Hr. Joachim Skovgaard, Hr. Niels Skovgaard, Conferentsraad Tang, Etatsraad Regenborg, Etatsraad Smith, Frøken V. Jensen, Greve og Grevinde Moltke, Nørager, Professor Stephens, Etatsraad Drewsen, Frøken Collet, Frøken Vøldiche, Etatsraadinde Brun, Frøken Friis, Fru Glahn, Fru Barnekow, Frøken Reeh, Frøken Andersen og jeg selv med mine to Sønner«. 
